\title{
EDITORIAL
}

\section{In This Issue: Capacity for Caring and Generating New Knowledge}

\author{
Kurt C. Stange, $M D, P b D$, Editor \\ Ann Fam Med 2006;4:386-388. DOI: 10.1370/afm.631.
}

$\mathrm{T}$ his issue presents research, theory, and commentary on a wide range of topics. Studies of the effects of health policy, health care, and how disease manifests are balanced by research and essays that address ways of knowing ourselves, health care phenomena, and conducting research. Two studies were conducted in practice-based research networks, and 4 use nationally or regionally representative data sets. In addition, this issue is accompanied by a supplement that explores the need for change in academic health centers (AHCs) and the critical role that family medicine can play in transforming AHCs to better meet the needs of the population.

\section{HEALTH CARE POLICY STUDIES}

Two studies ${ }^{1,2}$ and an editorial ${ }^{3}$ address the effects of health insurance on access to care and how care is provided. This research shows that accessibility, a fundamental tenet of the quality of primary care, is profoundly affected by the health care system context of practice. Further, family physicians, in tailoring their care to patient's situations, frequently try to take access to care into account in their management decisions. Ironically, in a health care system in which primary care is poorly supported financially, adapting care to patients' financial situation has the potential to result in care that is poorer in quality according to evidence-based guidelines.

A qualitative study examines the effect of mandatory reporting of elder abuse and finds paradoxical effects on physicians' thinking and action. ${ }^{4}$ This study shows how simple, well-meaning policies can lead to complexity and ambiguity at the point of application that alter the intended consequences.

A study using a sophisticated surveillance system for in-hospital medical injuries finds that estimates of injuries are inflated if comorbidity is not accounted for in the analysis. ${ }^{5}$ This finding may be useful in reconsidering previously reported high rates of attribution of deaths to medical injuries. ${ }^{6}$
Fortin and colleagues ${ }^{7}$ discover that psychological distress is associated with severity-adjusted multimorbidity. This finding has policy implications for designing systems that integrate care for mental and physical health (rather than carving out mental health care). The findings also should alert clinicians to be aware of psychological distress among patients with multiple and severe chronic illnesses and should alert mental health professionals to consider the conjoint effects of physical illness in patients with psychiatric symptoms.

\section{CLINICAL STUDIES}

Previously, a study by the Oklahoma Practice Research Network found a high prevalence of night sweats among adult patients. ${ }^{8}$ A new study in this network finds that night sweats are associated with a number of other sleep disturbances. The findings may begin to identify a syndrome of coexisting sleep problems and can help clinicians identify these syndromes by asking related questions when one sleep problem is identified.

Another study adds to the evidence about the detrimental effects of undiagnosed diabetes. Using nationally representative data, Koopman and colleagues find that among people with undiagnosed diabetes, $27 \%$ have a positive screening test for nephropathy and $22 \%$ have a positive screening test for neuropathy. ${ }^{9}$ Both these conditions occur at more than twice the rate they do for people without diabetes, although the association with neuropathy is not significant after controlling for age. Although the US Preventive Services Task Force currently recommends screening for type 2 diabetes only in adults with hypertension or hyperlipidemia, ${ }^{10}$ this study raises additional concerns about the premature morbidity caused by undiagnosed diabetes.

Guidelines for prostate cancer screening call for discussing with patients the potential benefits and possible harms of prostate-specific antigen (PSA) screening and considering patient preferences so physicians can make an individualized decision about whether 
to screen. ${ }^{11}$ The study by McFall and colleagues uses nationally representative data to examine testing with prostate-specific antigen (PSA). ${ }^{12}$ They find that discussion of advantages and disadvantages precedes $63 \%$ of PSA testing and is more likely for African American men, those with a usual source of care, and when physicians initiate the testing.

\section{RESEARCH CAPACITY FOR FAMILY MEDICINE}

Two studies in this issue relate to research funding and capacity. Rabinowitz and colleagues analyze NIH funding to US family medicine departments in 2003, finding some interesting patterns. ${ }^{13}$ The 17 investigator-initiated (R01) awards to family physicians represent only $0.055 \%$ of the 30,886 R01 grants awarded in that year. ${ }^{14}$ Katerndahl and Crabtree study the 10 year outcomes of a methodological think tank held at a national primary care research meeting. ${ }^{15}$ They find evidence of success in fostering funded research and identify aspects of the process that appear to be helpful. If knowledge is to be generated to meet the needs of the patients and problems cared for in primary care, more programs of this type are needed.

\section{KNOWLEDGE, HISTORY, AND MEANING}

In an important theory analysis that should crystallize our ways of thinking, communicating, and acting, Thomas explicates 3 theories of knowledge. ${ }^{16}$ This exposition is a practical guide for clinical practice, inquiry, and learning.

An essay by Stein takes a personal and historical perspective in characterizing the identity of the discipline of family medicine. ${ }^{17}$ He describes conflicting views of the content, boundaries, and identity that have exemplified American family medicine. These conflicts and the broader cultural context have led to valuing limited expertise over generalism.

An essay by Candib ${ }^{18}$ explores the many possible meanings of the word "yes." Based on a personal interaction with a friend learning English, she discovers that "yes" does not always suggest agreement or understanding and, when spoken by patients, can be a cue for the physician to probe more deeply.

\section{SUPPLEMENT: SHAPING THE FUTURE OF ACADEMIC HEALTH CENTERS}

This issue is accompanied by a supplement that explores the crucial role of family medicine in the evolution of academic health centers (AHCs). The supplement features 5 case studies ${ }^{19-23}$ and accompanying commentaries. ${ }^{24-28}$ It is introduced by an overview of relevant historical and policy issues, ${ }^{29}$ and a leadership dialogue based on the insightful interaction that occurred when earlier versions of these papers were presented at the 2005 Annual Meeting of the Association of American Medical Colleges. ${ }^{30}$ The supplement demonstrates that family medicine is poised to lead AHCs in increasing the relevance of their role, and deepening and expanding the relationships that are needed to meet this mission. This broadened role includes external relationships with communities and internal relationships within the AHCs themselves. The supplement addresses one of the major recommendations of the Future of Family Medicine Project, which called for family medicine departments "to enhance their contribution to the advancement and rejuvenation of the academic health center to meet the needs of the American People,"31 and to convene a summit to begin this important work.

We encourage readers to share experiences and ideas by joining the Annals online discussion at http:// www.AnnFamMed.org.

To read or post commentaries in response to this article, see it online at http://www.annfammed.org/cgi/content/full/4/5/386.

\section{References}

1. Carlson MJ, DeVoe JE, Wright B. Short-term impacts of coverage loss in a Medicaid population: early results from a prospective cohort study of the Oregon Health Plan. Ann Fam Med. 2006;4:391-398.

2. Meyers DS, Mishori R, McCann J, Delgado J, O’Malley A, Fryer E. Primary care physicians? Perceptions of the effect of insurance status on clinical decision-making. Ann Fam Med. 2006;4:399-402.

3. Derose K, Lurie N. Reliving history and renewing the health care reform debate. Ann Fam Med. 2006;4:388-390.

4. Rodriguez MA, Wallace S, Woolf N, Mangione C. Mandatory reporting of elder abuse: between a rock and a hard place. Ann Fam Med. 2006;4:403-409.

5. Meurer LN, Yang H, Guse C, Russo C, Brasel K. Excess mortality due to medical injury. Ann Fam Med. 2006;4:410-416.

6. Kohn LT, Corrigan JM, Donaldson MS, eds. To Err is Human. Building a Safer Health System. Washington, DC: National Academy Press; 2000.

7. Fortin M, Bravo G, Hudon C, LaPointe L, Dubois M, Almirall J. Psychological distress and multimorbidity in primary care. Ann Fam Med. 2006;4:417-422.

8. Mold JW, Roberts M, Aboshady HM. Prevalence and predictors of night sweats, day sweats, and hot flashes in older primary care patients: an OKPRN study. Ann Fam Med. 2004;2:391-397.

9. Koopman RJ, Mainous AG, Liszka HA, et al. Evidence of nephropathy, peripheral neuropathy in undiagnosed diabetes. Ann Fam Med. 2006;4:427-432.

10. Screening for type 2 diabetes mellitus in adults: recommendations and rationale. Ann Intern Med. 2003;138:212-214. Available at: http://www.guideline.gov/summary/summary.aspx?doc_id=3523.

11. US Preventive Services Task Force. Screening for Prostate Cancer: Recommendations and Rationale. Agency for Healthcare Research and Quality, Rockville, MD. Available at: http://www.ahrq.gov/ clinic/3rduspstf/prostatescr/prostaterr.htm.

12. McFall SL. US men discussing prostate-specific antigen tests with a physician. Ann Fam Med. 2006;4:433-436. 
13. Rabinowitz HK, Becker J, Gregory N, Wender R. NIH funding in family medicine: an analysis of 2003 awards. Ann Fam Med. 2006;4:437-442.

14. Department of Health and Human Services. National Institutes of Health. Computer Retrieval of Information on Scientific Projects (CRISP). Available at: http://crisp.cit.nih.gov/crisp/crisp_query.generate_screen. Accessed: 23 August 2006.

15. Katerndahl D, Crabtree BF. Creating innovative research designs: the 10-year methodological think tank case study. Ann Fam Med. 2006;4:443-449.

16. Thomas P. Primary care professionals need to be aware of the theories on which our work depends. Ann Fam Med. 2006;4:450-454.

17. Stein HF. Family medicine's identity: being generalists in a specialist culture? Ann Fam Med. 2006;4:455-459.

18. Candib LM. Sí, doctora. Ann Fam Med. 2006;4:460-462.

19. Kaufman A, Derksen D, Alfero C, et al. The health commons and care of New Mexico's uninsured. Ann Fam Med. 2006;4(Suppl 1):S21-S26.

20. Schwenk TL, Green LA. The Michigan clinical research collaboratory: following the NIH roadmap to the community. Ann Fam Med. 2006;4(Suppl 1):S41-S46.

21. Magill MK, Lloyd R, Palmer D, Terry S. Successful turnaround of a university owned, community-based, multidisciplinary practice network. Ann Fam Med. 2006;4(Suppl 1):S31-S37.

22. Smith JK, Weaver D. Capturing medical students' idealism. Ann Fam Med. 2006;4(Suppl 1):S50-S55.
23. Berg AO, Norris T. A workforce analysis informing medical school expansion, admissions, support for primary care, curriculum, and research (University of Washington). Ann Fam Med. 2006;4(Suppl 1):S12-S16.

24. Roth P. Managing the uninsured with a community network. Ann Fam Med. 2006;4(Suppl 1):S27-S30.

25. Roper WL, Newton WP. The role of academic health centers in improving health. Ann Fam Med. 2006;4(Suppl 1):S47-S49.

26. Krugman RD. Commentary on Utah primary care experience. Ann Fam Med. 2006;4(SUppl 1):S38-S40.

27. Eckhert NL. Getting the most out of medical students' global health experiences. Ann Fam Med. 2006;4(Suppl 1):S56-S57.

28. Rourke J. Social accountability in theory and practice. Ann Fam Med. 2006;4(Suppl 1):S17-S20.

29. Newton WP, DuBard C. Shaping the future of academic health centers: the potential contributions of departments of family medicine. Ann Fam Med. 2006;4(Suppl 1):S2-S11.

30. Michener JL, Powell DE, Susman JL, et al. Family medicine and the evolution of academic health centers: a dialog with leadership. Ann Fam Med. 2006;4:S58-S60

31. Martin JC, Avant RF, Bowman MA, et al for the Future of Family Medicine Project Leadership Committee. The future of family medicine: a collaborative project of the family medicine community. Ann Fam Med. 2004;2(Suppl 1):S3-S32.

\section{EDITORIAL}

\section{Reliving History and Renewing the Health Care Reform Debate}

Katbryn Pitkin Derose, $\mathrm{PbD}, \mathrm{MPH}$

Nicole Lurie, MD, MSPH

RAND Health, Santa Monica, Calif, and Arlington, Va
A s the 2008 presidential elections approach, health care reform is once again easing its way into the consciousness of many Americans. At last count, 48 million of them-nearly one fifth of

Conflicts of interest: none reported

\section{CORRESPONDING AUTHOR}

Kathryn Pitkin Derose, PhD, MPH

RAND Health

1776 Main St

Santa Monica, CA 90401-3208

derose@rand.org those younger than 65 years-lacked health insurance, ${ }^{1}$ and signs abound that the cost of health insurance is now a problem for both the middle class and the nation's economy. The importance of health insurance in obtaining health care and ensuring health has been documented for several decades, as have the effects of going without it. For example, more than 20 years ago, Lurie et $\mathrm{al}^{2,3}$ and Witcher and Fihn ${ }^{4}$ studied populations whose health insurance (Medicaid and Veterans Administration benefits, respectively) were terminated. Both studies documented significant declines in access to care as well as worsened health status, hypertension, and diabetes control. Furthermore, in the Medicaid 